\title{
Павло Гай-Нижник
}

доктор історичних наук,

заступник директора,

Науково-дослідний інститут українознавства МОН України

(Київ, Україна), hai-nyzhnyk@ukr.net

ORCID: https://orcid.org/oooo-ooo2-8912-8398

\section{Ігор Фурман}

доктор історичних наук, доцент,

начальник кафедри історії війн і воєнного мистецтва,

Національний університет оборони України ім. І.Черняховського

(Київ, Україна), fi.2005@ukr.net

ORCID: https://orcid.org/oooo-ooo2-3594-5499

\section{Державна жандармерія ЗУНР-3О УНР: зародження та інституціалізація (1918-1919 рр.)}

DOI: https://doi.org/10.15407/uhj2021.03.049

УДК: 94:338.43(=411.16)(477)《І8/19»

\begin{abstract}
Анотація. Мета статті полягає у висвітленні процесу формування державної жандармерії Західноукраїнської Народної Республіки впродовж 1918-1919 рр. Методологія дослідження побудована на принципах історизму, об'єктивності, багатофакторності й усебічного аналізу, а також на сучасному термінологічному апараті. Використано системний і структурний методи. Наукова новизна. На підставі архівних, частина яких уперше вводиться в науковий обіг, та опублікованих джерел проаналізовано організаційноправові засади встановлення інституту та структур державної жандармерії у ЗУНР$3 О$ УНР. Наведено статистичні дані стосовно кількісного й територіального складів служби. Указано місця дислокації жандармерії, ії кількісний склад, керівні органи, функції, обов'язки, завдання. Зауважено на тому, хто саме міг служити в лавах державної жандармерії та які вимоги висувалися до кандидатів. Окрему увагу звернено на утримання жандармів, їхню заробітну платню, пільги, доплати, рівень харчового забезпечення тощо. Наголошено на ролі жандармерії як за умов мирного часу, так і під час воєнних дій. У висновках зазначено про незавершеність процесу становлення державної жандармерії, iï переформатування й перепідпорядкування в період воєнних невдач та, зрештою, ліквідацію внаслідок краху західноукраїнської державності.
\end{abstract}

Ключові слова: ЗУНР, $3 О$ УНР, державна жандармерія, польова сторожа, народна сторожа.

Відновлення державності на західноукраїнських землях було проголошено I9 жовтня I9І8 р. Українською Національною Радою. Фактично ж ії встановлено після розвалу Австро-Угорської імперії й унаслідок силового (революційного) захоплення влади у Львові Українською генеральною командою на чолі з Д.Вітовським г листопада I9I8 р. Початково було проголошено Українську Державу, натомість назву Західноукраїнська Народна Республіка (ЗУНР) визначено на засіданні УНРади 9 листопада 1918 р. До складу ЗУНР, окрім Східної Галичини, входили також Північна Буковина й Закарпаття. Конституцією закріплювалося верховенство та суверенітет народу, який здійснював їх через представницькі органи, обрані на підставі загального, 
рівного, прямого виборчого права при таємному голосуванні за пропорційною системою.

Для забезпечення внутрішнього порядку замість розпущеної колишньої австрійської жандармерії, в якій в основному служили поляки, частково австрійці та в незначній кількості українці, було утворено українську жандармерію. Оскільки в Австрії, на відміну від Росії, жандармерія була не політичною, а загальною поліцією, замість неї місцеві комісари з перших днів існування ЗУНР формували так звану народну міліцію. Часто вона обиралася на зборах, вічах. Зазначимо принагідно, що у Чернівцях буковинські делегати УНРади скликали 25 жовтня I9I8 р. нараду своїх членів, які брали участь у львівських зборах, представників українських партій і товариств. На цьому зібранні було створено Український крайовий комітет Буковини (голова О.Попович) - Буковинську делегатуру УНРади. Також було започатковано й низку комісій із завданням підготувати всі сфери майбутнього державного життя на Буковині, зокрема Комісію народної оборони (голова О.Безпалко), котра мала зайнятися організацією міліції у Чернівцях та у краї загалом ${ }^{2}$.

Проте це все було місцевою самодіяльністю, а держава потребувала організованих і дисциплінованих органів охорони громадського порядку. Тому вже 6 листопада I9I8 р. УНРада ухвалила рішення про створення Корпусу української державної жандармерії․ На цю воєнізовану структуру покладалися функції охорони порядку, боротьби зі злочинністю й контрабандою, запобігання правопорушенням, протидії шпигунству та дезертирству, охорони тилу армії, майна, комунікацій, проведення реквізицій в інтересах війська тощо. Присягу жандармів приймав державний секретар Л.Цегельський, а першим їх командиром став сотник (згодом отаман) М.Федитник. У системі державної жандармерії діяли школа вищих офіцерів, школи командирів станиць (при окружних і повітових командах), пробних жандармів.

Уже го листопада I9I8 р. у своєму першому наказі («приказ ч. І») командант Л.Індишевський указував, що жандармерія й надалі несе службу на основі дотеперішніх приписів. Також зазначалося, що на той момент ще не функціонували деякі відділи жандармерії, а тому кожен повітовий командант мав самостійно «провадити» свій повіт. При цьому додавалося, що командантами можуть бути й німці (натомість представники інших національностей - ні), якщо вони прихильно ставляться до української державницької справи та за умови, що проти них не заперечує повітова національна рада. Л.Індишевський закликав усі команди жандармерії до негайного зорганізування й надіслання точних звітів про свою роботу й розміщення (відомості про політичне становище і про перебіг організації мали надсилатися щотижня). За браку службовців кожен повітовий командант мав повноваження дообрати так званих «пробних жандармів». При цьому «побори» для всіх жандармів залишалися такими самими, як і за австрійського правління. Окремо наголошувалося на відстежуванні більшовицького руху.

Начальна команда жандармерії (керівники - Л.Індишевський, а з лютого I919 p. О.Красіцький) розміщувалася у Львові, згодом ії переведено до Тернополя, а відтак до

\footnotetext{
1 Докл. див.: Гай-Нижник П. ЗУНР-3О УНР: становлення органів влади і державного управління (1918-1919 рр.). К., 2018. - 146 c.

2 Новосівський I.M. Українська державна влада на Буковині в 1918 р. - Нью Йорк, 1964. - С.10-11.

3 Державний архів Львівської обл. (далі - ДАЛО). - Ф.257. - Оп.1. - Спр.72. - Арк.63; Ф.1259. - Оп.1. - Спр.1. Арк.2.

4 Там само. - Ф.1259. - Оп.1. - Спр.1. - Арк.2.
} 
Станіславова (нині Івано-Франківськ). Офіційною мовою була українська. Невдовзі на засновану посаду інспектора жандармерії було призначено полковника колишньої австрійської жандармерії О.Гаванського'. Підрозділи міліції підпорядковувалися державній жандармерії як допоміжні формування ${ }^{6}$. Згідно із законом «Про тимчасову адміністрацію областей Західноукраїнської Народної Республіки», повітові військові команданти й команданти жандармерії підлягали повітовим комісарам винятково в питаннях громадської безпеки․

I4 листопада I9I8 р. товариш (заступник) державного секретаря внутрішніх справ Р.Перфецький своїм наказом оголосив рескрипт Державного секретаріату внутрішніх справ №8, в якому наказувалося всім українським повітовим комісарам та всім іншим політичним властям ЗУНР «дати негайно повну поміч Команді української жандармерії в зорганізованню публічної служби безпеченства. Всім зарядженням (розпорядженням - Aвm.) команданта української державної жандармерії безуслівно підчинитись» ${ }^{8}$. Подібний наказ усім українським військовим командам того ж дня видав і державний секретар військових справ Д.Вітовський 9.

У грудні I9I8 р. було створено також польову сторожу (жандармерію), якою командував О.Красіцький. Вона діяла при штабах армійських бригад (відділи по зо5о осіб), корпусів (сотні по гоо-Іо вояків). Головні завдання польової сторожі полягали у збереженні ладу в місцях дислокації й пересування військ, у зборі та охороні військового майна, особливо зброї, боєприпасів, у запобіганні диверсійним акціям на залізничних шляхах, мостах, лініях зв'язку, у протидії дезертирству, супроводженні конвоїв і кур'єрів тощо (у місцях, де ще не було державної жандармерії, підрозділи сторожі іноді виконували також ії обов'язки). Правовою базою діяльності нової структури стали «Організаційні постанови для польової жандармерії Галицької армії» та службова інструкція, оголошені наказом командування УГА від г2 березня I9I9 p.

Українська державна жандармерія підпорядковувалася Державному секретаріату військових справ ЗУНР. На місцях створювалися військово-територіальні області, окружні та повітові команди жандармерії, а також сільські й міські станиці. Загалом жандармерія мала 23 відділи (в містах крайової дислокації: Львів, Перемишль, Ярослав, Сянок, Самбір, Сокаль, Рава-Руська, Городок, Дрогобич, Тернопіль, Теребовля, Чортків, Бучач, Броди, Золочів, Бережани, Стрий, Калуш, Станіславів, Городисько, Коломия, Чернівці, Сторожинець) ${ }^{\text {го }}$. На місцях продовжувала діяти також і народна міліція, що формувалася на громадських засадах шляхом виборів. Державна жандармерія не підпорядковувалася цивільним та військовим установам чи громадським організаціям, проте вони мали право звертатися до неї з проханнями про допомогу в межах їі компетенціі. Крім того, з огляду на розвиток оперативної ситуації повітовим державним комісарам, судовим органам, прокура-

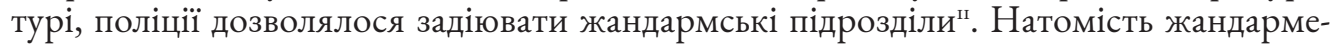

\footnotetext{
5 Центральний державний історичний архів України, м. Львів (далі - ЦДІАЛ України). - Ф.581. - Оп.1. - Спр.163. - Арк.44.

${ }^{6}$ Центральний державний архів вищих органів влади та управління України. - Ф.1092. - Оп.3. - Спр.107. Арк.1, 6; Козак I. Дещо про державну жандармерію ЗУНР // Український скиталець. - 1923. - Ч.16. C.25.

Діло. - 1918. - 18 падолиста.

8 ДАЛО. - Ф.1259. - Оп.1. - Спр.1. - Арк.5.

, Там само.

${ }_{10}$ Там само. - Спр.33. - Арк.113.

${ }^{11}$ Гай-Нижник П. Інститут державних повітових комісарів, повітових національних рад та жандармерії у 3УНР // Становлення і розвиток української державності. - Вип.7: Матеріали VI Всеукраїнської науково-практичної конференції «Державне управління та місцеве самоврядування в Україні в контексті європейської інтеграції», м. Київ, МАУП. - К., 2012. - С.17-31.
} 
рія мала повноваження вимагати в поліції, цивільної, військової влади сприяння у вирішенні поставлених перед нею завдань, запрошувати громадян на бесіди у службових питаннях ${ }^{12}$.

Законом від І5 лютого 1919 р. УНРада здійснила реорганізацію жандармерії. За основу було взято відповідний австрійський закон від 25 грудня I894 р. Відтепер регламентувався правовий статус, окреслювалася структура, термін служби (не менше 4 років), вимоги до кандидатів на службу та їі відбуття (відповідно до ухваленого табелю про ранги), порядок використання зброї, критерії до службовців, соціальні гарантії для них тощо. Так, жандарм мав право застосувати зброю під час несення служби в разі «конечної оборони» (при відбитті нападу на нього особисто чи на інших осіб, який загрожує життю, за умови вчинення опору затримуваною особою, при спробі втечи небезпечного злочинця).

Кандидат на службу в державній жандармерії мав бути громадянином ЗУНР віком від 20 до 40 років із бездоганним способом життя, добрими моральними рисами, меткою вдачею, неодруженим чи бездітним удівцем, високим на зріст, фізично здоровим і розвинутим, грамотним (уміти читати, писати, рахувати), зі знанням державної та мови тієї частини неукраїнського населення, яке проживає на теритоpiï, де нестиметься його служба (винятки щодо вікових чи сімейних обмежень кожній окремій особи міг надати лише державний секретар внутрішніх справ або, за його вказівкою, командант державної жандармерії). Що стосувалося одруження, то старшина в ранзі полковника мав отримати на це дозвіл в очільника держави, підполковник і нижчі чини (до десятника включно) - у державного секретаря внутрішніх справ. Служба в державній жандармерії зараховувалася як військова. У питаннях громадської безпеки жандармерія підпорядковувалася державним повітовим комісарам, а у військових, господарсько-адміністративних, підготовки кадрів та контролю служби - повітовим командантам. При Державному секретаріаті внутрішніх справ було створено VI відділ жандармерії й поліції на чолі з майором Ю.Волощуком (замість скасованої посади інспектора жандармерії). Воєнізація структури посилювалася й тим, що на службовців відтепер поширювалися армійські дисциплінарні статути ${ }^{13}$.

У повітах також створювалися команди жандармерії на чолі з повітовими командирами (командантами) - останнім підлягали сільські й міські станиці жандармерії. Для рядових службовців зауважувалося: «3 населенєм треба поводити ся як найкраще, щоби не давати причин до негодовань і заворушень. На большевицький рух звертати пильну увагу, а про всі прояви його повідомляти нечайно команду» ${ }^{14}$. Станом на лютий І9І9 р. було сформовано І8 місцевих органів державної жандармерії.

Як зазначалося в наказі Начальної команди Української державної жандармерії №2, повітовим командиром міг бути призначений «бувший повітовий командант, о скілько він є українцем або нїмцем»돈 а за відсутності таких - найближчий старший за ранґом українець чи німець, «о скільки вони прихильні нашій справі та проти них повітова Українська Національна Рада нїчого 6 не мала» ${ }^{16}$.

Для жовнірів жандармерії визначалася платня (щоденно): стрілець - 50 сотників («заслуження») і г крона («воєнний додаток»); старший стрілець - 7о сот. та

\footnotetext{
${ }^{12}$ Стечишин A.B. Кость Левицький - творець національного інституту жандармерії ЗУНР // Науково-інформаційний вісник Івано-Франківського університету права ім. короля Данила Галицького: Серія «Право». - Вип.3. - ІваноФранківськ, 2017. - С.118.

${ }^{13}$ ЦДІАЛ України. - Ф.581. - Оп.1. - Спр.163. - Арк.17-20, 47.

14 ДАЛО. - Ф.1259. - Оп.1. - Спр.1. - Арк.2.

15 Там само. - Арк.5.

${ }_{16}$ Там само. - Арк.2.
} 
I кр. 30 сот.; вістун - I кр. і 2 кр.; десятник - І кр. 20 сот. та 2 кр. 8о сот.; старший десятник - 2 кр. і 4 кр.; булавний десятник - 2 кр. 50 сот. та 4 кр. รо сот. Офіцери мали отримувати: хорунжий - 200 кр. («місячно») і 5 кр. («бойовий додаток денно»), 40 кр. квартирних на місяць («для I кляси») або 20 кр. («для II кляси»); четар 250 кр. («місячно») і 6 кр. («бойовий додаток денно»), 8о кр. квартирних на місяць («для I кляси») або 40 кр. («для II кляси»); поручник - зоо кр. («місячно») i 7 кр. («бойовий додаток денно»), І6о кр. квартирних на місяць («для I кляси») або 80 кр. («для II кляси»); сотник - 350 кр. («місячно») та го кр. («бойовий додаток денно»), 40 кр. квартирних на місяць («для I кляси») або 20 кр. («для II кляси»). Усі жандарми отримували харчові пайки, а в разі відмови від них - 5 кр. 20 сот. щоденно. Крім того, існував також жандармський додаток для старшин, а саме для булавного офіцера - гоо кр., для сотника - 8 о кр., для поручника й четаря - по 50 кр., для хорунжого - 20 крон $^{17}$.

Жандарми отримували не лише платню, але й подорожні кошти (на день): булавний офіцер - 40, офіцер - 25, повітовий вахмістр - 6 крон. Із військових складів виділялося харчування (на г особу): сніданок - г пайка консервованої каші; обід - 300 г м’яса, І кг картоплі або 200 г круп, гороху, квасолі, 300 г капусти, 30 г солі, 5 г цибулі/часнику, 2 мл оцту та 20 г борошна; вечеря - 500 г картоплі або Іоо г круп, гороху, квасолі і І5о г капусти. До цього щоденно додавалося 500 г хліба або $30 о$ г сухарів. Для прокорму коней виділялося на день: 3 кг вівса, 5 кг сіна, І кг соломи ${ }^{18}$.

Для несення служби на залізниці рішенням Державного секретаріату військових справ від 24 березня 1919 р. було створено залізничну жандармерію (командант Ю.Буцманюк, згодом М.Яворський $)^{19}$. До іï функцій належали перевірка документів у військових і цивільних пасажирів, виявлення й затримання підозрілих осіб із підробленими документами, шпигунів, провокаторів, крадіїв, гарантування порядку в поїздах, охорона державного майна, що перевозилося залізницею. Залізнична жандармерія користувалася правами державної жандармерії ЗУНР. Лінійні осередки у складі 8-2о осіб на кожний відділок діяли у г4 населених пунктах (Станіславів, Ходорів, Тернопіль, Стрий, Самбір, Чортків, Коломия, Красне, Броди, Підволочиськ, Гусятин, Лавочне, Ворохта, Бережани) ${ }^{20}$.

4 квітня I9I9 р. Державний секретаріат внутрішніх справ своїм розпорядженням «В справі підвищення поборів жандармів і мужви без рангів при державній жандармерії» впорядкував роль і повноваження жандармських службовців. При Команді державної жандармерії існував «доповняючий відділ», що займався організацією теоретичного навчання (вишколу) пробних жандармів і підготовкою станичних командантів ${ }^{21}$. Наприкінці 1918 р. у Станіславові було відкрито жандармську школу для «здібних, інтеліґентних та ідейних хлопців з війська, що заявили охоту стало служити при жандармерії» ${ }^{22}$. За пропозицією I.Макуха при Державному секретаріаті внутрішніх справ було засновано школу державної жандармерії, метою якої була підготовка керівного складу. Тут також працювали курси для поліцейських підстаршин.

\footnotetext{
${ }_{17}$ Там само. - Спр.33. - Арк.114.

18 Там само. - Арк.113-115.

${ }^{19}$ Сiдак B.C., Степанков В.С. 3 історії української розвідки та контррозвідки (нариси). - К., 1994. - С.195.

${ }_{20}$ Див.: [Електронний ресурc] http://exlibris.org.ua/sidak/r5-p2.html

${ }^{21}$ ЦДІАЛ України. - Ф.581. - Оп.1. - Спр.163. - Арк.44.

22 Тищик Б.Й., Вівчаренко О.А. Західноукраїнська Народна Республіка. - Коломия, 1993. - С.84.
} 
Із ліквідацією у червні 1919 р. Державного секретаріату внутрішніх справ жандармерію було перепідпорядковано спочатку Начальній команді УГА, відтак команді запілля НК УГА, а згодом - військовій канцелярії диктатора $3 О$ УНР Є.Петрушевича. Після того, як бойові дії перейшли на терени УНР, що раніше перебували під владою Російської імперії, у липні г9ı9 р. державну жандармерію перейменували в «народну сторожу» (аби уникнути небажаних асоціацій у місцевого населення). На літо того року в ії складі нараховувалося до г тис. (у липні понад I,5 тис.) «заводових» (кваліфікованих), 40о «пробних» жандармів, 4 тис. стажистів, 6 булавних старшин, 25 (30) сотенних старшин і хорунжих ${ }^{23}$. До органів охорони громадського порядку входили також майже 3 тис. народних міліціонерів. Референтом (запроваджена посада) державної жандармерії став майор I.Дичка ${ }^{24}$.

24 червня I919 р. відповідним наказом було оголошено про видання нового статуту для польової жандармерії (тоді нею командував сотник М.Яворський), яким передбачалися певні зміни в організаційному устрої, у тому числі змінено назву на «польова сторожа».

Після переходу у другій половині літа г9І9 р. уряду 30 УНР і командування УГА через р. Збруч та прибуття до Кам’янця-Подільського у складі державної жандармерії нараховувалося (за неточними відомостями) 25 старшин, 900 «заводових», 250 «пробних» жандармів і 2 тис. міліціонерів. Щоправда останніх чи не відразу ж було переведено в підпорядкування команди запілля НК УГА для відправки на фронт, а із «заводових» жандармів сформували 8 відділів державної жандармерії (забезпечували загальний порядок, несли допоміжну військову службу в районі дій УГА, а відділ сотника Ващука здійснював охорону диктатоpa 30 УНР). Після ж переходу частини галицької армії на бік більшовиків народну сторожу було розпущено, старшин і жандармів розподілили по бригадах, а певна кількість службовців влилася до лав Дієвої армії та органів безпеки УНР. Інша частина колишніх жандармів з окремими підрозділами УГА перейшла через Карпати до Чехословаччини ${ }^{25}$. На початок 1920 р. державна жандармерія припинила своє існування.

\section{REFERENCES}

1. Havrylenko, O., Lytvyn, M., Yarmysh, O. (2005). Zhandarmeriia Zakhidnoukrainskoi Narodnoi Respubliky. Entsyklopediia istorii Ukrainy, 3, 139. Kyiv. [in Ukrainian].

2. Hai-Nyzhnyk, P. (2018). ZUNR-ZO UNR: stanovlennia orhaniv vlady i derzhavnoho upravlinnia (1918-1919 rr.). Kyiv. [in Ukrainian].

3. Hai-Nyzhnyk, P. (2012). Instytut derzhavnykh povitovykh komisariv, povitovykh natsionalnykh rad ta zhandarmerii u ZUNR. Stanovlennia i rozvytok ukrainskoi derzhavnosti, 7, 17-31. Kyiv. [in Ukrainian].

4. Hutsal, P. (2008). Derzhavna zhandarmeriia ZUNR. Ternopilskyi entsyklopedychnyi slovnyk, 3, 480. Ternopil. [in Ukrainian].

5. Novosivskyi, I.M. (1964). Ukrainska derzhavna vlada na Bukovyni v 1918 r. Niu-York. [in Ukrainian].

6. Sidak, V.S., Stepankov, V.S. (1994). Z istorii ukrainskoi rozvidky ta kontrrozvidky (narysy). Kyiv. [in Ukrainian].

7. Stechyshyn, A.V. (2017). Kost Levytskyi - tvorets natsionalnoho instytutu zhandarmerii ZUNR. Naukovo-informatsiinyi visnyk Ivano-Frankivskoho universytetu prava im. korolia Danyla Halytskoho. Seriia: Pravo, 3, 115-122 [in Ukrainian].

8. Tyshchyk, B., Vivcharenko, O. (1993). Zakbidno-Ukrainska Narodna Respublika. Kolomyia. [in Ukrainian].

\footnotetext{
${ }^{23}$ ЦДІАЛ України. - Ф.581. - Оп.1. - Спр.163. - Арк.17-18; Козак I. Дещо про державну жандармерію ЗУНР // Український скиталець. - 1923. - Ч.16. - С.27-28; Ч.17/18. - С.16.

${ }^{24}$ Гавриленко О., Литвин М., Ярмиш О. Жандармерія Західноукраїнської Народної Республіки // Енциклопедія історії України. - Т.3. - К., 2005. - С.139; Гущал П. Державна жандармерія ЗУНР // Тернопільський енциклопедичний словник. - Т.3. - Тернопіль, 2008. - С.480.

${ }^{25}$ Козак I. Дещо про державну жандармерію ЗУНР // Український скиталець. - 1923. - Ч.17/18. - С.23-24.
} 


\title{
Pavlo HAI-NYZHNYK
}

Doctor of Historical Sciences (Dr. Hab. in History),

Head's Assistant,

Research Institute of Ukrainian Studies MES of Ukraine

(Kyiv, Ukraine), hai-nyzhnyk@ukr.net

ORCID: https://orcid.org/oooo-ooo2-8912-8398

\section{Ihor FURMAN}

Doctor of Historical Sciences (Dr. Hab. in History), Docent,

Head at Department of History of Wars and Military Art,

National Defence University of Ukraine named after I.Cherniakhovskyi

(Kyiv, Ukraine), fi.2005@ukr.net

ORCID: https://orcid.org/oooo-ooo2-3594-5499

\section{State Gendarmerie of WUPR-WR UPR: Organization and Institutionalization (1918-1919)}

\begin{abstract}
The purpose of the article is to cover the process of formation of the Ukrainian state gendarmerie of Western Ukrainian People's Republic during 1918-1919. The research methodology is based on the principles of historicism, objectivity, multifactorial and comprehensive analysis, as well as modern terminology. System and structural methods are used. Scientific novelty. On the basis of archival, some of which are introduced into scientific circulation for the first time, and published sources, the organizational and legal principles of establishing the institute and structures of the state gendarmerie in the WUPR-WR UPR - are analyzed. Statistical data on the quantitative and territorial composition of the gendarmerie service are given. The locations of the gendarmerie, its number, governing bodies, functions, duties and tasks of this law enforcement service are indicated. It was noted who could serve in the ranks of the state gendarmerie and what were the requirements for candidates for gendarmes. Particular attention is paid to the maintenance of gendarmes, their salaries, benefits and surcharges, the level of food security and more. The role of the gendarmerie is indicated both in peacetime and during hostilities. The conclusion indicates the incompleteness of the process of formation of the state gendarmerie, its reformatting and re-subordination during the military failures of the Ukrainian Halychyna Army and, finally, liquidation due to the fall of Western Ukrainian statehood.
\end{abstract}

Keywords: Western Ukrainian People's Republic (WUPR), Western Region of Ukrainian People's Republic (WR UPR), state gendarmerie, field guard, people's guard. 